\title{
Maya Index dan Kepadatan Larva Aedes aegypti di Daerah Endemis Demam Berdarah Dengue Kelurahan Labuh Baru Timur Kecamatan Payung Sekaki Kota Pekanbaru
}

\author{
Esy Maryanti ${ }^{1 *}$, Suri Dwi Lesmana ${ }^{1}$, Dhewa Triguna ${ }^{2}$, Martin Plymoth ${ }^{3}$, Wida Harmas ${ }^{2}$, Delly $^{2}$, Afiata $^{2}$,
} Mislindawati $^{1}$

\begin{abstract}
Dengue hemorrhagic fever (DHF) is an infectious disease that can result in death, caused by dengue virus and transmitted through Aedes aegypti mosquitoes. The incidence of dengue fever every year, requires more serious attention to increasing awareness of the disease. The purpose of this study was to determine the Maya Index (MI) and density of Aedes aegypti larvae in Labuh Baru Timur subdistrict, Payung Sekaki, Pekanbaru city. Method of the reseach was survey research using questionnaire and larva identification using single larva method method. A total of 131 houses that have been surveyed got 589 containers. MI status based on breeding risk index and hygiene risk index, found high as many as 23 houses (17.58\%). Free number of larvae of 67.94, Container index (CI) of 8.32, House Index (HI) 32.06 and Breteau index of 37. HI and CI figures are still high that has not met the government target. The density of larvae is on the 3 - 5 scale, ie the medium category, meaning that the area has a medium transmission risk to the spread of DHF.
\end{abstract}

Keywords : Aedes aegypti, maya index, kepadatan larva, demam dengue

Demam berdarah dengue (DBD) merupakan salah satu penyakit yang sampai saat ini masih menjadi masalah kesehatan di Indonesia. Penyakit ini merupakan penyakit infeksi yang dapat berakibat kematian. Penyakit ini disebabkan oleh virus dengue yang ditularkan melalui nyamuk. Vektor utama penyakit DBD adalah nyamuk Aedes aegypti. ${ }^{1,2}$ Pengobatan untuk penyakit ini belum ditemukan, sehingga tindakan pencegahan yang harus ditingkatkan dalam mengatasi tingginya angka kejadian penyakit tersebut. Insiden DBD meningkat di seluruh dunia dalam beberapa dekade terakhir. Jumlah kasus DBD di Indonesia cenderung meningkat dari tahun ke tahun. Data Departemen Kesehatan Republik Indonesia pada tahun 2014, menunjukkan penderita DBD sebanyak 100.347 kasus dengan jumlah kematian 907 orang. ${ }^{3}$

\footnotetext{
* Penulis untuk korespondensi : esy.maryanti@gmail.com

1 KJF Parasitologi Fakultas Kedokteran Universitas Riau, Pekanbaru, Riau

2 Fakultas Kedokteran Universitas Riau, Pekanbaru, Riau

3 Faculty of Medicine, University of Milan, Italy
}

Kasus DBD di Pekanbaru dari tahun ke tahun meningkat yaitu 113 kasus (2013), 209 kasus (2014) 516 kasus (2015) dan 793 kasus (2016) yang tersebar di 12 kecamatan. Kecamatan dengan kasus tertinggi adalah Kecamatan Payung Sekaki ( 145 kasus) dan kasus terendah dilaporkan di Kecamatan Sail (25 kasus $)^{4}$

Angka kejadian DBD yang terus meningkat setiap tahun, memerlukan perhatian serius agar kewaspadaan terhadap penyakit tersebut meningkat dan mencegah kejadian luar biasa (KLB) DBD di Pekanbaru. Hal yang dapat dilakukan adalah mengukur kepadatan larva dengan cara Angka Bebas Jentik (ABJ), House Index (HI), Container Index (CI) dan Breteau Index (BI). Selain kepadatan larva, dapat juga dilakukan pengukuran Maya Index yang dapat digunakan untuk mengindentifikasi suatu area berisiko tinggi sebagai tempat perkembangbiakan (breeding site) nyamuk Aedes sp. didasarkan pada status kebersihan lingkungan atau HRI (hygiene risk index) dan ketersediaan tempat-tempat yang mungkin berpotensi sebagai tempat perkembangbiakan 
nyamuk atau BRI (breeding risk index). ${ }^{5}$ Oleh karena itu perlu dilakukan penelitian untuk menentukan maya index dan kepadatan larva Aedes aegypti di daerah endemis Kota Pekanbaru.

\section{METODE}

Jenis penelitian yang digunakan adalah penelitian deskriptif analitik dengan pendekatan cross sectional study. Penelitian dilakukan pada bulan Agustus - September 2017 di daerah endemis DBD di Pekanbaru yaitu Kelurahan Labuh Baru Timur, Kecamatan Payung Sekaki dengan angka kejadian DBD tertinggi tahun 2016. Populasi yang menjadi subjek penelitian ini adalah seluruh rumah (Kepala Keluarga/KK) yang berada di Kelurahan Labuh Baru Timur. Sampel yang diambil dengan cara simple random sampling dengan jumlah sampel 131 rumah. Peneliti memeriksa tempat penampungan air (TPA) yang ada di dalam rumah dan di luar rumah (Controllable site (CS), Disposable site (DS) dan Uncotrollable site (UCS)), dan jentik yang ditemukan diperiksa dengan metode single larva method yaitu larva yang ditemukan diambil dan dibawa ke Laboratorium Parasitologi Fakultas Kedokteran Universitas Riau untuk diperiksa secara mikroskopik. Setelah mendapat data jumlah TPA dan jumlah TPA positif jentik Aedes aegyptimaka dihitung kepadatan larva yaitu ABJ, CI, HI, BI. Kemudian untuk menghitung Maya Index maka ditentukan terlebih dahulu BRI dan HRI. BRI adalah jumlah TPA atau kontainer yang ada di dalam rumah tersebut dibagi dengan rata-rata TPA di dalam rumah di daerah tersebut, sedangkan HRI adalah jumlah kontainer yang ada di luar rumah dibagi dengan ratarata kontainer di luar rumah di daerah tersebut yang dihitung tiap rumah. Untuk menentukan kategori BRI dan HRI di rumah tangga tersebut digunakan rumus : jika tinggi $=X>(\hat{i}+1,0$ SD $)$, sedang $=(\hat{i}-1,0$ SD) d" $X<\grave{i}+1,0$ SD, rendah $=X<(\grave{i}-1,0$ SD $)$. Setelah itu dimasukkan ke dalam tabel matrik 3x3 untuk menentukan Maya Index. ${ }^{6}$

\section{HASIL}

Penelitian ini dilakukan pada 131 rumah di Kelurahan Labuh Baru Timur, Kecamatan Payung Sekaki Kota Pekanbaru. Sampel terdiri dari seluruh tempat penampungan air atau kontainer yang ada di dalam rumah dan luar rumah. Data yang telah dikumpulkan selama bulan Agustus sampai September 2017 terdiri dari 589 kontainer dari 131 rumah.

Tabel 1. Distribusi Frekuensi Kontainer berdasarkan Kategori di Kelurahan Labuh Baru Timur pada Agustus - September 2017

\begin{tabular}{|c|c|c|}
\hline Kategori & Jumlah (\%) & Positif \\
\hline \multicolumn{3}{|l|}{ Jenis } \\
\hline Controllable Site (CS) & $550(93,38 \%)$ & $43(87,76 \%)$ \\
\hline Disposable Site (CS) & $26(4,41 \%)$ & $6(12,24 \%)$ \\
\hline Undercontrollable Site (US) & $13(2,21 \%)$ & 0 \\
\hline \multicolumn{3}{|l|}{ Bahan } \\
\hline Semen & $76(12,90 \%)$ & $3(6,12 \%)$ \\
\hline Keramik & $89(15,11 \%)$ & $1(2,04 \%)$ \\
\hline Plastik & $398(67,57 \%)$ & $39(79,59 \%)$ \\
\hline Logam & $11 \quad(1,87 \%)$ & $6(12,25 \%)$ \\
\hline Karet & $5(0,85 \%)$ & 0 \\
\hline Kaca & $10 \quad(1,70 \%)$ & 0 \\
\hline \multicolumn{3}{|l|}{ Tertutup/Tidak } \\
\hline Tertutup & $76(12,9 \%)$ & $6(12,24 \%)$ \\
\hline Tidak & $513(87,1 \%)$ & $43(87,76 \%)$ \\
\hline \multicolumn{3}{|l|}{ Perkiraan Volume } \\
\hline$>20 \mathrm{~L}$ & $208(35,31 \%)$ & $20(40,82 \%)$ \\
\hline $1-20 \mathrm{~L}$ & $288(48,90 \%)$ & $19(38,78 \%)$ \\
\hline$<1 \mathrm{~L}$ & $93(15,79 \%)$ & $10(20,40 \%)$ \\
\hline Total & $589(100 \%)$ & $49(100 \%)$ \\
\hline
\end{tabular}


Berdasarkan tabel 1, dapat dilihat bahwa jenis kontainer yang banyak ditemukan di daerah Kelurahan Labuh Baru Timur adalah Controllable sites yaitu sebanyak 550 (93,38\%), dan dari bahan kontainer yang terbanyak adalah jenis bahan plastik sebanyak $67,57 \%$, dengan kontainer yang tidak tertutup (87,1\%). Berdasarkan perkiraan volume kontainer yang terbanyak ditemukan yaitu 1 - 20 liter (48,90\%).

Pada pemeriksaan laboratorium dari larva yang ditemukan dengan metode single larva method didapatkan hasil positif larva Aedes aegypti yaitu sebanyak 49 dari 589 kontainer yaitu 8,3\%. Sebanyak
87,76\% kontainer yang positif larva Aedes aegypti terdapat pada kontainer jenis controllable sites, sedangkan pada jenis uncontrollable sites tidak ditemukan adanya larva.Berdasarkan bahan kontainer, hasil positif banyak ditemukan pada kontainer dengan bahan plastik yaitu sebesar 79,59\% dan dilihat dari tertutup atau tidaknya kontainer, kontainer yang tidak tertutup yang banyak ditemukan larva Aedes aegypti yaitu sebesar $87,76 \%$, dan berdasarkan perkiraan volume kontainer, kontainer dengan volume $>20 \mathrm{~L}$ tidak terlalu berbeda hasil positifnya dengan kontainer yang perkiraan volumenya sekitar $1-20 \mathrm{~L}$.

Tabel 2. Jumlah Tempat Penampungan Air (TPA) di Kelurahan Labuh Baru Timur pada Agustus September 2017

\begin{tabular}{lcc}
\hline \multicolumn{1}{c}{ Jenis TPA } & Jumlah & Positif \\
\hline Controllable sites & 550 & 6 \\
Bak Mandi & 158 & 11 \\
Ember & 109 & 4 \\
Bak air & 100 & 13 \\
Drum & 51 & 2 \\
Wadah Kulkas & 8 & 0 \\
Dispenser & 14 & 0 \\
Tempat minum burung & 11 & 2 \\
Talang Air & 47 & 4 \\
Pot Bunga & 50 & 1 \\
Gentong & 2 & \\
Disposable sites & 26 & 4 \\
Kaleng Bekas & 13 & 2 \\
Ban Bekas & 5 & 0 \\
Botol Bekas & 8 & \\
Under controllable sites & 13 & 0 \\
Kolam ikan & 4 & 0 \\
Aquarium & 9 & 49 \\
\hline Total & 589 & \\
\hline
\end{tabular}

Pada tabel 2, dapat dilihat kontainer controllable sites yang diperiksa ada 550 buah kontainer dengan kontainer terbanyak yang diperiksa adalah bak mandi, tetapi hasil positif larva Aedes aegypti banyak ditemukan pada kontainer jenis drum. Pada kontainer disposable sites yang banyak positif ditemukan pada kontainer jenis kaleng bekas, sedangkan pada kontainer uncontrollable sites tidak ditemukan larva Aedes aegypti.

Tabel 3. Distribusi Frekuensi Rumah Berdasarkan BRI dan HRI di Kelurahan Labuh Baru Timur pada Agustus - September 2017

\begin{tabular}{ccc}
\hline Kategori & Breeding risk index & Hygiene risk index \\
\hline Rendah & $11(8,40 \%)$ & $92(70,23 \%)$ \\
Sedang & $98(74,81 \%)$ & $27(20,61 \%)$ \\
Tinggi & $22(16,79 \%)$ & $12(9,16 \%)$ \\
Total & $131(100 \%)$ & $131(100 \%)$ \\
\hline
\end{tabular}


Pada tabel 3 dapat dilihat bahwa BRI di Kelurahan Labuh Baru Timur banyak terdapat di kategori sedang yaitu 74,81\%, sedangkan HRI terbanyak terdapat pada kategori rendah yaitu 70,23\%. Status Maya Index pada Kelurahan ini dapat dilihat pada tabel 4.

Tabel 4. Distribusi Frekuensi Rumah berdasarkan status Maya Index di Kelurahan Labuh Baru Timur pada Agustus - September 2017

\begin{tabular}{lcc}
\hline Maya Index & Jumlah & $\%$ \\
\hline Rendah & 89 & 66,92 \\
Sedang & 19 & 14,50 \\
Tinggi & 23 & 17,58 \\
Total & 131 & 100 \\
\hline
\end{tabular}

Status Maya Index pada Kelurahan Labuh Baru Timur didapatkan terbanyak pada kategori rendah yaitu 66,93\% dan 17,58\% rumah ditemukan pada kategori tinggi.
Pengukuran kepadatan larva Aedes aegypti, dapat dilakukan dengan mengukur angka bebas jentik, container index, house index dan breteau index yang dapat dilihat hasilnya pada tabel 5.

Tabel 5. Indikator index larva Aedes aegypti di Kelurahan Labuh Baru Timur pada Agustus - September 2017

\begin{tabular}{lc}
\hline \multicolumn{1}{c}{ Indikator Index Larva } & Hasil \\
\hline Angka Bebas Jentik (ABJ) & $67,94 \%$ \\
Container Index (CI) & $8,32 \%$ \\
House Index (HI) & $32,06 \%$ \\
Breteau Index (BI) & $37,00 \%$ \\
\hline
\end{tabular}

\section{PEMBAHASAN}

Pada penelitian ini didapatkan jumlah kontainer sebanyak 589 kontainer dari 131 rumah yang diperiksa. Berdasarkan jumlah kontainer tersebut didapatkan jenis controllable sites yang terbanyak ditemukan. Menurut Miller, ${ }^{6}$ controllable sites adalah kontainer yang dapat dikendalikan oleh manusia dengan cara menguras dan menutup untuk mencegah perkembangbiakan nyamuk Aedes aegypti. Disposable sites merupakan jenis kontainer yang tidak dapat dikontrol karena merupakan sampah dan biasanya terdapat di luar rumah serta tidak dapat digunakan dalam rumah tangga, tetapi apabila terisi air hujan dapat menjadi tempat perkembangbiakan nyamuk jika tidak dibersihkan atau dikubur dalam tanah. Undercontrollable sites adalah tempat-tempat yang berisi air yang selalu terkontrol, seperti kolam dan aquarium yang berisi ikan dan tidak ditemukan larva Aedes aegypti. ${ }^{5}$

Jumlah CS yang tinggi dan DS yang rendah pada rumah di Kelurahan Labuh Baru Timur menandakan bahwa masyarakat didaerah tersebut sudah dapat menjaga kebersihan lingkungan, karena DS merupakan jenis kontainer yang biasanya merupakan sampah seperti kaleng bekas, ban bekas dan botol bekas tempat yang berisiko tinggi untuk perkembangbiakan nyamuk. Berdasarkan penelitian dari 26 DS, ditemukan 23\% positif larva Aedes aegypti.

Jumlah jentik yang tinggi ditemukan pada drum tempat penampungan air karenamasyarakat jarang membersihkannya, selain itu wadah di bawah kulkas juga ditemukan jentik Aedes aegypti. Wadah tersebut kadang berisi air dan sering lupadibersihkan. Pada penelitian di Denpasar, ${ }^{5}$ didapatkan hasil bahwa bak mandi merupakan kontainer yang paling banyak ditemukan jentik hal ini dikarenakan masyarakat terlambat untuk membersihkan bak mandi minimal seminggu sekali.

Status maya index merupakan indikator untuk mengetahui sebuah lingkungan berisiko sebagai tempat perkembangbiakan nyamuk Aedes aegypti, yaitu dengan melihat ketersediaan tempat-tempat 
yang berpotensi sebagai tempat perkembangbiakan nyamuk dan status kebersihan lingkungan. ${ }^{6}$ Maya index dapat dihitung dengan menentukan terlebih dahulu breeding risk index (BRI) dan hygiene risk index (HRI). Pada hasil penelitian didapatkan BRI terbanyak pada kategori sedang dan HRI terbanyak ditemukan pada kategori rendah, BRI dengan kategori tinggi ditemukan 16,79\%, BRI tinggi ini menunjukkan banyak ditemukan CS dan memiliki risiko lebih besar terjadi perkembangbiakan nyamuk. HRI menggambarkan kebersihan rumah, semakin tinggi HRI maka semakin kotor rumah tersebut, ${ }^{5-7}$ pada penelitian ini didapatkan HRI yang tinggi sebanyak 9,16\%. Berdasarkan BRI dan HRI tersebut didapatkan status maya index, pada rumah di Kelurahan Labuh Baru Timur didapatkan status maya index terbanyak adalah pada status rendah yaitu 66,92\%. Penelitian ini dilakukan pada musim kemarau dan ditemukan kategori tinggi sebesar $17,58 \%$, hal ini mungkin dapat meningkat jika dilakukan pada musim penghujan yang diduga tempat-tempat penampungan air dengan jenis kontainer disposable sites akan meningkat.

Menurut WHO kepadatan larva Aedes aegypti dapat dinilai menggunakan density figure (DF) yaitu dengan melihat CI, HI dan BI. Hasil penelitian didapatkan nilai angka bebas jentik (ABJ) sebesar 67,94\%, angka ini masih kurang dari 95\% yang menggambarkan belum tercapainya target pemerintah. Pemerintah menetapkan indikator keberhasilan dari program pengendalian DBD jika ABJ > 95\%. ${ }^{8}$ Penelitian sebelumnya di Kelurahan Limbungan Baru Kecamatan Rumbai Pesisir Pekanbaru didapatkan ABJ 57,77\%. ${ }^{9}$ Angka bebas jentik kurang dari 95\% merupakan salah satu faktor risiko terhadap peningkatan kasus DBD. Berdasarkan jumlah kontainer yang diperiksa didapatkan CI sebesar 8,32\%, berarti melebihi standar dari WHO yaitu $<5 \% .{ }^{10}$ Container index menggambarkan informasi tentang banyaknya jumlah penampungan air yang positif larva. CI $>5 \%$, menunjukkan bahwa banyak terdapat kontainer sebagai tempat perkembangbiakan larva Aedes aegypti yang merupakan vektor DBD.

House index penelitian kami sebesar 32,06\%, hasil tersebut sama dengan penelitian di Padang tahun $2014(30 \%)^{11}$ dan penelitian di Semarang tahun 2014 (24,24\%). ${ }^{12}$ House index menggambarkan persentase rumah yang positif larva, apabila ditemukan ada satu kontainer yang positif larva Aedes aegypti, maka rumah tersebut sudah dianggap positif larva Aedes aegypti. Angka Breteau index di Kelurahan Labuh Baru Timur didapatkan 37\%. Angka kepadatan larva ini (CI, HI dan BI) apabila dihubungkan dengan menggunakan angka kepadatan vektor atau density figure (DF) dari WHO maka Kelurahan Labuh Baru Timur termasuk pada skala 3 dan 5. Dilihat dari HI dan BI maka DF nya pada skala 5, sedangkan berdasarkan CI pada skala 3 dan secara keseluruhan dapat disimpulkan berdasarkan skala density figure dari WHO, kepadatan larva di Kelurahan Labuh Baru Timur Pekanbaru berada pada kategori sedang. Arti dari DF sedang adalah bahwa Kelurahan Labuh Baru Timur memiliki risiko penularan sedang terhadap penyebaran penyakit DBD.

\section{KESIMPULAN}

Status Maya Index pada Kelurahan Labuh Baru Timur didapatkan terbanyak pada kategori rendah. Angka bebas jentik, container index, house index dan Breteau index masih belum mencapai target program pemerintah. Berdasarkan skala density figure dari WHO didapatkan kepadatan larva di Kelurahan Labuh Baru Timur Kecamatan Payung Sekaki Kota Pekanbaru berada pada kategori sedang yang artinya bahwa daerah tersebut memiliki risiko penularan sedang terhadap penyebaran penyakit DBD.

\section{UCAPAN TERIMA KASIH}

Ucapan terima kasih disampaikan kepada Lembaga Penelitian dan Pengabdian Kepada Masyarakat Universitas Riau yang telah mendanai penelitian ini.

\section{DAFTAR PUSTAKA}

1. Soegijanto S, Salamun, Yotopranoto S. Nyamuk Aedes aegypti sebagai vektor penyakit demam berdarah dengue. Dalam : Soegijanto S. Demam Berdarah Dengue Tinjauan dan Temuan Baru di Era 2003. Jakarta;2004.

2. Soedarto. Demam berdarah dengue. Jakarta: Sagung Seto; 2012. 
3. Departemen Kesehatan (Depkes) Republik Indonesia 2014. Profil Kesehatan Indonesia tahun 2014.

4. Dinas Kesehatan Kota Pekanbaru. Angka kejadian demam berdarah dengue tahun 2016 di Pekanbaru, Pekanbaru: Dinas Kesehatan Kota Pekanbaru;2016.

5. Purnama SG, Baskoro T.Maya Index dan Kepadatan larva Aedes aegypti terhadap infeksi dengue. Makara Kesehatan.2003;16 (2): 57-64.

6. Miller JE, Martinez-Balanzar A, Gazga-Salinas D. Where Aedes aegypti live in Guerrero; using the Maya Index to measure breeding risk. In: Halstead SB, Gomez-Dantes H. Editors. Dengue: a worldwide problem, a common strategy. Mexico, D.F.: Ministry of Health, Mexico, and Rockefeller Foundation; 1992.p.311-317.

7. Pascawati, NA. Survei entomologi dan penentuan maya index di daerah endemis DBD di Dusun Krapyak Kulon Desa Panggung harjo Kecamatan Sewon, Kabupaten Bantul DIY. Jurnal Medika Respati.2015; 10 (3).
8. Departemen Kesehatan Republik Indonesia. Modul pengendalian demam berdarah dengue tahun 2011. Jakarta: Direktorat Jenderal Pengendalian Penyakit dan Penyehatan Lingkungan;2011.

9. Nesa H. Gambaran Kepadatan larva Aedes aegypti di daerah endemis dan non endemis demam berdarah dengue Kecamatan Rumbai Pesisir Pekanbaru.[Skripsi]. Pekanbaru:Fakultas Kedokteran Universitas Riau;2015.

10. World Health Organization. A review of entomological sampling methods and indicators for dengue vectors.2015. (cited 2016 October). Available from: http://www.who.intl/tdr/ publicatiobs/documents/dengue

11. Adrial. Penentuan indikator entomologi penyakit demam berdarah dengue (DBD) di daerah endemis Kotamadya Padang.[Skripsi]. Padang: Universitas Andalas;2014.

12.Santi, D., Budiono, I. and Wahyono, B. Aedes aegypti (studi kasus di Kelurahan Sukorejo, Kecamatan Gunungpati, Kota Semarang Tahun 2014. Unnes Journal of Public Health.2014; 4(1): pp. 69-75. 